\title{
LIPID COMPOSITION AND IN VITRO BIOSYNTHETIC RATES OF NEUTRAL LIPIDS AND PHOSPHATIDYLCHOLINE IN ANTERIOR AND POSTERIOR CHAMBERS OF THE GOLDFISH SWIMBLADDER
}

\author{
Byron A. Doneen* and David H. Gutmann \\ Division of Biological Sciences, The University of Michigan, Ann Arbor, MI 48109, U.S.A.
}

(Received 16 September 1980)

\begin{abstract}
Lipid composition was compared in anterior and posterior swimbladder and also in lavages of both chambers in the goldfish.

2. Anterior bladder contained more phosphatidylethanolamine and sphingomyelin than posterior chamber, but phosphatidylcholine contents were similar.

3. Cholesterol formed $17 \%$ of lipids in lavage-fluid in anterior chamber and $30 \%$ in posterior chamber. Iavage phospholipid contents in four pooled samples of each chamber were below detectable limits. Thus, surface-active phospholipids do not appear to be secreted by either chamber of goldfish swimbladder.

4. Uptake and incorporation of $\left[{ }^{14} \mathrm{C}\right]$-acetate into total lipids, cholesterol and free fatty acids was greater in anterior than in posterior chamber. Rates of $\left[{ }^{3} \mathrm{H}\right]$ methylcholine incorporation into phosphatidylcholine were similar in both chambers.

5. Goldfish anterior and posterior swimbladder display differences in lipid composition and metabolism which may be related to functional specializations.
\end{abstract}

\section{INTRODUCTION}

The phystomatous swimbladder of the goldfish, $\mathrm{Car}$ assuius auratus, is a two-chambered organ. On account of its attachment to Weberian ossicles, the anterior chamber has been implicated in sound perception (Evans, 1925). The posterior chamber receives the pneumatic duct and serves a hydrostatic function. Since gas gland cells specialized for gas secretion are poorly developed in cyprinids (Fänge, 1976), goldfish generally rely on swallowed air to fill the swimbladder.

Swimbladder lipids have functional and evolutionary importance. Functionally these compounds are necessary for control of buoyancy. In benthic teleosts, swimbladder lipids, especially cholesterol and certain phospholipids, seem important for maintenance of high oxygen content during hyperbaric conditions (Phleger \& Benson, 1971; Phleger \& Holtz, 1973). Some lipids, such as low-density cholesterol and wax esters may contribute directly to equalization of specific gravity at various depths (reviewed by Blaxter $\&$ Tytler, 1978). Of considerable evolutionary interest is the close relationship between swimbladder lipids and lipids forming the pulmonary surfactant secreted by specialized cells in the lungs of mammals (Mason, 1976), birds (Marin et al., 1978; Hylka \& Donecn, 1980) and some lower vertebrates (Meban, 1978; Pattle, 1976), including air-breathing fish (Phleger \& Saunders, 1978).

In contrast to benthic and mesopelagic species, little information is available on composition and

\footnotetext{
* To whom all correspondence should be addressed.
}

function of swimbladder lipids in surface-dwelling teleosts, such as the goldfish. The ultrastructural study of Morris \& Albright (1979) identified simiantype lamellar bodies in the pneumatic duct of the goldfish. As simian-type lamellar bodies are associated with surfactant production in primate lungs (Williams, 1977), pneumatic duct may synthesize a surfactant-like substance. Non-simian type lamellar bodies observed in lungs of non-primate mammals (Creasey et al., 1974), were also described in the anterior chamber of the goldfish swimbladder, whereas lamellar bodies of either type were not observed in posterior chamber (Morris \& Albright, 1979). On the other hand, Pattle (1976) was unable to detect surfaceactivity (reduced surface tension indicative of surfactant-like substances) in lavages of goldfish swimbladder. In view of the contrasting implications of the electron microscopic and surface-activity results, and because of clear functional and ultrastructural differences between its anterior and posterior portions, separate chambers and lavages of the goldfish swimbladder were examined for differences in lipid composition. The synthetic rates of cholesterol, triglycerides, free fatty acids and phosphatidylcholine were also measured in both chambers in vitro using two radioactively-labelled lipid precursors. This study was not concerned with the pneumatic duct.

\section{MATERIALS AND METHODS}

\section{Lipid extraction and identification}

Anterior and posterior chambers from swimbladders in goldfish measuring $7-10 \mathrm{~cm}$ in length were pooled into 4 samples of 4 chambers each. After the swimbladders were 
Table 1. Lipid and cholesterol contents of anterior and posterior chambers of the goldfish swimbladder*

\begin{tabular}{lccc}
\hline & Anterior & Posterior & $P$ \\
\hline Wet weight (mg) & $39.5 \pm 9.4$ & $22.7 \pm 9.7$ & $<0.05$ \\
Total lipid (mg/mg protein) & $0.10 \pm 0.04$ & $0.10 \pm 0.05$ & $\mathrm{NS}$ \\
Cholesterol (mg/mg lipid) & $0.14 \pm 0.02$ & $0.13 \pm 0.02$ & $\mathrm{NS}$ \\
\hline
\end{tabular}

* Values are mean $\pm \mathrm{SE} ; n=4$ pooled samples of 4 chambers each.

+ Student's $t$-test (one-sided): $\mathrm{NS}=$ not significant.

dissected from fish, each chamber was lavaged 3 times, using a syringe loaded with $1 \mathrm{ml} 0.9 \%$ saline. Lipid extraction was performed according to the method of Folch et $a$, (1957). Duplicate aliquots were taken for protein determinations (Lowry et al. 1951). Total lipid content was measured gravimetrically after evaporation of solvent and dessication over $\mathrm{KOH}$. The lipid sample was then diluted with chloroform-methanol $(2: 1)$ and $500 \mu \mathrm{g}$ applied to 2 TLC plates (Whatmann LKSD). Another aliquot was used for total lipid phosphorous determination according to Bartlett (1959). One set of plates was developed using a solvent which resolved polar lipids (chloroform-methanol water $65: 35: 5$ ) with phosphatidylcholine $(\mathrm{PC}$ ) phosphatjdylethanolamine (PE) and Sphinomyelin (S) standards (LePage, 1964). The duplicate set of TLC plates was developed using a nonpolar double-solvent system ( $n$-hexane dimethylether-acetic acid 90:10:1 followed by same components, 70:30:2) (Mangold, 1964), with cholesterol. tripalmitin, and palmitic acid as standards. Lanes on one-half of each plate were sprayed (phosphomolybdic acid. $100^{\circ} \mathrm{C} \times 10 \mathrm{~min}$ for identification of standards. Sample lanes on the other half of the plate were used for elution and quantitative analysis. Cholesterol was measured spectrophotometrically after reaction of gels with acid dichromate at $100^{\circ} \mathrm{C}$ for $45 \mathrm{~min}$ (Amenta, 1964). Phosphorous content was measured (Bartlett, 1959) in phospholipids eluted from gels as described by Biezenski (1964).

\section{$\left[{ }^{14} \mathrm{C}\right]$ Acetate incorporation}

Four pooled anterior and posterior chamber samples $(3$ chambers each) were obtained from 12 goldfish. Tissues were rinsed with $0.9 \%$ saline, minced and incubated in $2 \mathrm{ml}$ goldfish Ringer's solution containing $0.72 \mu \mathrm{C} / \mathrm{ml}$ of $\left[{ }^{14} \mathrm{C}\right]$ acetate $(44 \mathrm{C} / \mathrm{mmol}$; New England Nuclear) for $2 \mathrm{hr}$ at $24^{\circ} \mathrm{C}$ under $95 \% \mathrm{O}_{2}-5 \% \mathrm{CO}_{2}$. Tissues were then cooled on ice and centrifuged. After 3 rinses with goldfish Ringer's, tissues were homogenized and neutral lipids extracted and separated as before. Fractions corresponding to choles- terol, tripalmitin, and palmitic acid standards were eluted from scraped gel with glacial acetic acid and $0.25 \mathrm{ml}$ methanol-water $(1: 1)$. Eluates were counted in $12 \mathrm{ml}$ toluenebased scintillation fluid (Omnifluor, New England Nuclear) also containing $4 \mathrm{ml}$ Triton $X-100$. Samples of tissue homogenate and total lipid extract were also counted. CPM were converted to DPM using a quench curve.

\section{$\left[^{3} H\right]$ Methylchotine incorporation}

The pooled tissues (4 groups of 3 chambers each) were minced and incubated as above $\left(0.30 \mu \mathrm{C} / \mathrm{ml}\right.$ of $\left[{ }^{3} \mathrm{H}\right]$ methylcholine chloride; $84 \mathrm{C} / \mathrm{mmol}$ : New England Nuclearl. After the $2 \mathrm{hr}$ incubation period, tissues were rinsed, lipids extracted and phospholipids separated as before. PC fractions were eluted and counted as described above.

\section{Statistics}

Differences between values observed in anterior and posterior chambers were compared using Student's t-test (onesided).

\section{RESULTS}

Mean wet weight of the anterior chamber was $75^{\circ}$, greater than posterior swimbladder (Table 1). When normalized with respect to protein content, equal amounts of lipid were extracted from each chamber (Table 1). Cholesterol content ( $\mathrm{mg} / \mathrm{mg}$ lipid) was also similar in anterior and posterior chamber. Results in Table 2 show that total phospholipid content (with respect to wet weight) was similar in the two chambers. However, in the anterior chamber phospholipid formed a significantly greater $(P<0.05)$ fraction of tissue lipid. Fractional PC content was similar in both chambers, but anterior tissue contained greater amounts of PE and $S$ (Table 2). Analyses of anterior and posterior chamber lavage

Table 2. Phospholipid composition of anterior and posterior chambers of the goldfish swimbladder*

\begin{tabular}{|c|c|c|c|}
\hline & Anterior & Posterior & $P^{\dagger}$ \\
\hline \multicolumn{4}{|l|}{ Lipid phosphorous } \\
\hline$(\mu \mathrm{mol} / \mathrm{g}$ wet wt) & $11.0 \pm 2.5$ & $10.0 \pm 2.7$ & NS \\
\hline$(\mu \mathrm{mol} / \mathrm{mg}$ lipid $)$ & $0.33 \pm 0.11$ & $0.21 \pm 0.08$ & $<0.05$ \\
\hline \multicolumn{4}{|l|}{ Phosphatidylcholine } \\
\hline (mg/mg lipid) & $0.132 \pm 0.032$ & $0.098 \pm 0.037$ & NS \\
\hline $\mathrm{PC}_{+}^{+}$ & $51.7 \pm 9.9$ & $61.0 \pm 14.9$ & NS \\
\hline \multicolumn{2}{|l|}{ Phosphatidylethanolamine } & $0.013 \pm 0.005$ & $<0.05$ \\
\hline$\% \mathrm{PE}_{+}^{+}$ & $13.2 \pm 1.4$ & $8.6 \pm 3.2$ & $<0.05$ \\
\hline Sphingomyelin (mg/mg lipid) & $0.034 \pm 0.017$ & $0.015 \pm 0.005$ & $<0.05$ \\
\hline$\%$ & $13.2 \pm 2.5$ & $9.4 \pm 1.9$ & $<0.05$ \\
\hline
\end{tabular}

* Values are mean $\pm \mathrm{SE}: N=4$ pooled samples of 4 chambers each.

+ Student's $t$-test (one-sided): NS $=$ not significant.

\# Mole $\%$ of total phospholipids. 
Table 3. Lipid composition of lavaged-fluids from anterior and posterior chambers of goldfish swimbladder*

\begin{tabular}{lccc}
\hline & Anterior & Posterior & $P^{\dagger}$ \\
\hline $\begin{array}{l}\text { Total lipid (mg/mg protein) } \\
\text { Cholesterol (mg/mg protein) }\end{array}$ & $0.36 \pm 0.09$ & $0.33 \pm 0.14$ & NS \\
$\begin{array}{l}\text { Lipid phosphorous } \\
(\mu \text { mol/chamber) }\end{array}$ & $0.064 \pm 0.010$ & $0.102 \pm 0.005$ & $<0.01$ \\
\hline
\end{tabular}

* Values are mean $\pm \mathrm{SE} ; N=4$ pooled samples of 4 chambers each.

+ Student's $t$-test (one-sided); NS $=$ not significant.

fluids are summarized in Table 3. Total amount of lipid obtained by lavage (normalized to protein content of lavaged chambers) was the same. Cholesterol content of lipid obtained by lavage, however, was $60 \%$ greater in the posterior chamber than in anterior. In both chambers the amount of phospholipid in pooled lavages from 4 animals fell well below limits of detectability. Failure to detect lipid phosphorus established an upper limit of less than $0.1 \mu$ mole phospholipid extracted by lavage in each chamber.

Table 4 summarizes the distribution of $\left[{ }^{14} \mathrm{C}\right]$ acetate among major neutral lipid classes after exposure to label for $2 \mathrm{hr}$. Uptake of label into tissue and its incorporation into total lipid, cholesterol, and fatty acids was significantly greater in anterior than in pos- terior chamber. Greater labeling of specific neutral lipid components in anterior chamber can be accounted for by the greater uptake of label by the tissue. An exception is the greater proportion of label located in the triglyceride fraction isolated from posterior chamber.

Data in Table 5 show no significant differences between chambers in $\left[{ }^{3} \mathrm{H}\right]$ methylcholine uptake and incorporation into total lipid and $\mathrm{PC}$. In both chambers, $69 \%$ of the label incorporated into lipid was observed in the PC fraction.

\section{DISCUSSION}

Lamellar bodies, indicative of lipid (especially phospholipid) secretion in the lung have also been ob-

Table 4. In vitro incorporation rates of $\left[{ }^{14} \mathrm{C}\right]$ acetate into neutral lipids of separate chambers of goldfish swimbladder*

\begin{tabular}{|c|c|c|c|}
\hline Incorporation rate in: & Anterior & Posterior & $P \dagger$ \\
\hline $\begin{array}{l}\text { Tissue } \\
\text { (DPM } \times 10^{-3} / \mathrm{mg} \text { wt weight) }\end{array}$ & $2.36 \pm 0.24$ & $1.61 \pm 0.13$ & $<0.01$ \\
\hline $\begin{array}{l}\text { Total lipid } \\
\left(\text { DPM } \times 10^{-3} / \mathrm{mg} \text { lipid }\right)\end{array}$ & $5.70 \pm 0.77$ & $3.47 \pm 0.51$ & $<0.01$ \\
\hline $\begin{array}{l}\text { Cholesterol } \\
\qquad\left(\mathrm{DPM} \times 10^{-3} / \mathrm{mg} \text { lipid }\right)\end{array}$ & $0.35 \pm 0.05$ & $0.24 \pm 0.02$ & $<0.01$ \\
\hline$\%$ Cholesterol + & $6.0 \pm 0.3$ & $7.1 \pm 1.1$ & NS \\
\hline $\begin{array}{l}\text { Triglycerides } \\
\left(\mathrm{DPM} \times 10^{-3} / \mathrm{mg} \text { lipid }\right)\end{array}$ & $1.03 \pm 0.17$ & $0.93 \pm 0.08$ & NS \\
\hline$\%$ Triglycerides $\ddagger$ & $17.9 \pm 1.0$ & $27.8 \pm 3.3$ & $<0.01$ \\
\hline $\begin{array}{l}\text { Free fatty acids } \\
\qquad\left(\mathrm{DPM} \times 10^{-3} / \mathrm{mg} \text { lipid }\right)\end{array}$ & $0.91 \pm 0.13$ & $0.43 \pm 0.09$ & $<0.01$ \\
\hline$\%$ Free fatty acids $\ddagger$ & $16.0 \pm 0.8$ & $12.4 \pm 2.6$ & $<0.05$ \\
\hline
\end{tabular}

* Values are mean DPM $\pm \mathrm{SEM} \times 10^{-3} ; N=4$ pooled samples of 3 chambers each.

$\uparrow$ Student's $t$-test (one-sided); NS $=$ not significant.

$+\%$ Of label in total lipid found in neutral lipid component.

Table 5. In vitro incorporation rates of $\left[{ }^{3} \mathrm{H}\right]$ methylcholine into anterior and posterior chambers and into tissue $\mathrm{PC}$ in goldfish swimbladder*

\begin{tabular}{lccc}
\hline Incorporation rate in: & Anterior & Posterior & $P \dagger$ \\
\hline $\begin{array}{l}\text { Tissue } \\
\quad 1 \text { DPM } \times 10^{-3} / \mathrm{mg} \text { wet wt) }\end{array}$ & $18.1 \pm 2.1$ & $23.7 \pm 1.6$ & NS \\
$\begin{array}{l}\text { Total lipid } \\
\quad \text { DPM } \times 10^{-3} / \mathrm{mg} \text { lipid) }\end{array}$ & $25.2 \pm 5.5$ & $23.3 \pm 2.6$ & NS \\
$\begin{array}{l}\text { Phosphatidylcholine } \\
\text { (DPM/mg lipid) }\end{array}$ & $17.3 \pm 3.9$ & $16.0 \pm 1.6$ & NS \\
$\%$ PC $\$$ & $68.5 \pm 1.1$ & $69.0 \pm 2.0$ & NS \\
\hline
\end{tabular}

*Values are mean + SE. $N=4$ pooled samples of 3 chambers each.

† Student's t-test; NS $=$ not significant.

$+\%$ Of label in total lipids observed in PC. 
served in the anterior chamber but are absent from the posterior chamber of the goldfish swimbladder (Morris \& Albright, 1979). This study has identified differences in lipid composition and in biosynthetic rates of some lipids in the two swimbladder chambers. Whereas total lipid and PC contents in the chambers were similar, the anterior segment was enriched in total phospholipids, PE and S (Table 2). The uptake of $\left[{ }^{14} \mathrm{C}\right]$ acetate was also greater in the anterior than in the posterior chamber (Table 4). This may support existence of accelerated lipid turnover in the anterior chamber. On the other hand, no evidence of phospholipid secretion by either chamber was obtained (Table 3 ). Though the methods used to analyze lavaged fluid could not have detected small amounts of phospholipid, the deficiency in polar lipids suggests absence of surfactant-like secretion, as proposed by Pattle (1976).

The presence of cholesterol in lavaged fluids (Table 3) from both chambers (Table 3) is consistent with secretion of this neutral lipid. Cholesterol content was greatest in lavaged fluid of the posterior chamber, the swimbladder segment most specialized for buoyancy control (Blaxter \& Tytler, 1978). Cholesterol constitutes one-half of the secreted lipid in swimbladders of some deep sea fishes (Phleger \& Holtz, 1973). Overall, the data imply that secretion of lipids into the airspace of goldfish swimbladder proceeds at a very low rate.

Neutral lipid biosynthetic rate, as measured by $\left[{ }^{14} \mathrm{C}\right]$ acetate incorporation, was greater in anterior than in posterior chamber (Table 4). However, increased radioactivity in neutral lipid components in this chamber was due to a greater rate of $\left[{ }^{14} \mathrm{C}\right]$ acetate uptake. Incorporation of $\left.\Gamma^{3} \mathrm{H}\right\rceil$ methylcholine identifies the terminal step in only one of three routes of PC synthesis, the CDP-Choline pathway (Weinhold et al., 1973). Therefore equivalent rates of incorporation of this label into total phospholipids and PC (Table 5) does not prove that total PC synthetic rates were identical in the two chambers. Since lamellar bodies are far less abundant in goldfish swimbladder than in mammalian lung (Morris \& Albright, 1979), lamellar body lipids form only a small proportion of total tissue lipids in the anterior chamber. Therefore. it will be necessary to isolate these organelles following pulse-chase exposure to specifically measure rates of synthesis of lamellar body lipids.

Despite its limited lipid and gas secreting capacities (Blaxter \& Tytler, 1978) the goldfish swimbladder shares some biochemical features with swimbladders of benthic teleosts. The major phospholipids in goldfish swimbladder (Table 2) and in three species of deepsea fishes (Phleger \& Holtz, 1973; Phleger et al., 1977) are PC, PE and S. As in goldfish (Tables 1 \& 2), swimbladders in abyssal fish display a phospholipidcholesterol ratio of approx 1:1 (Phleger et al., 1977).

\section{SUMMARY}

The goldfish swimbladder is divided into anterior and posterior chambers which have become specialized for separate functions. Functional differences may be associated with the presence of lamellar bodies in the anterior chamber, and with the absence of these organelles in the posterior chamber (Morris
\& Albright, 1979). Differences observed in lipid composition and rates of $\left[{ }^{14} \mathrm{C}\right]$ acetate uptake reflect, in part, distinct patterns of lipid metabolism in anterior and posterior chambers of the goldfish swimbladder.

\section{REFERENCES}

AMENTA J. S. (1964) A rapid chemical method for quantification of lipids by thin-layer chromatography. J. Lipid Res. 5, 270-272.

Bartlett G. R. (1959) Phosphorous assay in column chromatography. $J$. biol. Chem. 234, 466-468.

BIENZENSKI J. J. (1964) Quantitation and preparation of phospholipids by elution following improved thin layer chromatography separation. Fedn Proc. 23, 503.

Blaxter J. H. S. \& Tytler P. (1978) Physiology and function of the swimbladder. Adr. comp. Physiol. Biochem. 7, 311-367.

Creasey J. M., Pattle R. E. \& Schock C. (1974) Ultrastructure of inclusion bodies in type II cells of lung. human and subsimian. J. Physiol 237, 35P-37P.

EVANS H. M. (1925) A contribution to the anatomy and physiology of the air-bladder and Weberian ossicles in Cyprinidae. Proc. R. Soc. B.97, 545576.

FÄNGE R. (1976) Gas exchange in the swimbladder. In Respiration of Amphibious Vertebrates (Edited by HuGHES G M.), pp. 123-137. Academic Press NY.

Folch J.. Lees M. \& Stanley G. H. S. (1957) A simple method for the isolation and purification of total lipides from animal tissues. J. biol. Chem. 226, 497-509.

HylKa V. \& DONEen B. A. (1980) The surfactant system in the embryonic chick lung: ontogeny of pulmonary lipid and its phospholipid and selected neutral lipid components. Manuscript submitted.

LEPAGF M. (1964) Isolation and characterization of an esterified form of a steryl glucoside. J. Lipid Res. 5. 587.592

Lowry O. H., Rosebrol:GH N. J., Farr A. L. \& Randall. R. J. (1951) Protein measurement with the Folin phenol reagent. J. biol. Chem. 193, 264-275.

MaNGOLD H. K. (1964) Thin layer chromatography of lipids. J. Am. Oil Chem. Soc. 38, 708-727.

Marin L.. Toridet C. \& Dameron F. (1978) The endocrine control of embryonic lung maturation in the chicken. I Morphological and biochemical differentiation of lungs. after in oro decapitation. Anat. Embryol. 152, 223224.

MAsoN R. J. (1976) Lipid metabolism. In Biochemical Busis of Pulmonary Function. Vol. 2 (Fdited by CRYSTAI. R. G.l. pp. 127-169. Dekker. NY.

MEBAN C. (1978) The respiratory epithelium in the lungs of the slow-worm. Auguis fragilis. Cell Tiss. Re's. 190, 337-347.

MORRIS S. M. \& ALbriciHT J. T. (1979) Ultrastructure of the swim bladder of the goldfish. Carassius auratus. Cell Tiss. Res. 198, $105 \cdot 117$.

Pattle. R. E. (1976) The lung surfactant in the evolutionary tree. In Respiration of Amphibious Vertebrates (Edited by Hughes G. M.), pp. 233-255. Academic Press, NY.

Phleger C. F. \& Binson A. A. (1971) Cholesterol and hyperbaric oxygen in swimbladders of deep sea fishes. Nature. Lond. 230, 120.

Phleger C. F. \& Hol.tz R. B. (1973) The membranous lining of the swimbladder in deep sea fishes. I. Morphology and chemical composition. Comp. Biochem. Physiol. 45D, $867 \cdot 873$.

Phleger C. F. \& Salinditrs B. S. (1978) Swim-bladder surfactants of Amazon air-breathing fishes. Cam. J. Zool. 56, 946952.

Phllger C. F., Holtz R. B. \& Grimis P. W. (1977) Membrane biosynthesis in swimbladders of deep sea fishes 
Coryphaenoides acrolepis and Antimorpha rostrata. Comp. Biochem. Physiol. 56B, 25-30.

Weinhold A. A., SANders R. \& STERN W. (1973) Regulation of choline phosphoglyceride synthesis during lung development in the rat. In Respiratory Distress Syndrome
(Edited by Villee C. A., Viliee D. B. \& Zuckerman J.), pp. 29-42. Academic Press, NY.

WiLliams M. C. (1977) Development of the alveolar structure of the fetal rat in late gestation. Fedn Proc. 36, 2653-2659. 